\title{
Diversity of Phylloplane Fungi Associated with Habenaria foliosaA. Rich.(Orchidaceae) from bhandara and chandrapur districts of Maharashtra
}

\author{
Ankush Kayarkar ${ }^{1}$, Nitin Dongarwar ${ }^{2}$ \\ Research student, Post Graduate Department of Botany, RTM Nagpur University, (MS) India ${ }^{1}$ \\ Assistant Professor, Post Graduate Department of Botany, RTM Nagpur University, (MS) India ${ }^{2}$
}

\begin{abstract}
The phylloplane of Habenaria foliosa- the endangered terrestrial orchid was studied from the two different localities of two different districts for to access the diversity of fungi over four different fungal media, present on the leaves. For the present investigation, the plants were collected from the Chandpur (Bhandara district) and Kurkheda (Gadchiroli district) in the months of July-August, 2015. In the present study, a total 22 fungal species with 13 genera were reported over the leaf surface.Penicillium and Aspergillus are found to be dominant followed by the Black sterile mycelia.
\end{abstract}

Keywords: Anamorphic fungi, Aspergillus, Forest, leaf surface, Penicillium.

\section{INTRODUCTION}

Phylloplane is the term first time used for to denote the leaf surface environment. Phylloplane is a natural habitat on the leaf surface which supports heterogeneous population comprising both pathogenic and non-pathogenic microorganisms [1].Plant leaf surface is always witnessed the external atmospheric changes occurred in the environment. The leaf surface constitutes a habitat for numerous micro-organisms like fungi and bacteria. The fungi growing on the leaf surface are referred as Phylloplane fungi[8]. Phylloplane fungi are classified into two groups viz. residents and casuals [11].Sah et al 2013 [12] sated that resident type of fungi can multiply on the surface of healthy leaves without affecting the host but casual species land on the surface of the leaf but cannot multiply themselves. Orchidaceae, one of the largest family of Angiosperms, represented by the beautiful colours and natural beauty of flowers. Their demand in the floriculture market is only because of their beautiful flowers and potted plants [7]. They are distributed in diverse habitat with modified vegetative and floral structures [6].

The populations of orchids are decreasing day by day because of their poor seed germination, low propagation rate and extensive collection from nature. Because of this, so many orchid taxa are now facing the threat of endangered category [9].Habenaria foliosa is a tuberous annual herb growing in the tropical and subtropical regions with flowering period of August-September [15]. The phylloplane microorganisms are found to play a role in nitrogen fixation, lignin and wax degradation, promote to senescence, production of growth regulators, and contribute in plant defence [5]. Therefore the present investigation is undertaken to know the diversity of Phylloplane fungi.

\section{MATERIALS \& METHODS}

\section{A. Plant collection}

To analyse the diversity of fungi on Habenaria foliosaleaves, the materials were collected from two different districts of Maharashtra state of India. The first site Chandpur, is located in Bhandara district at N21 ${ }^{\circ} 28.795^{\prime}$ E $79^{\circ} 08.865^{\prime}$ and the second site Kurkheda, is located at N20 $0^{\circ} 13.259^{\prime}$ E $80^{\circ} 41.442^{\prime}$ in Gadchiroli district.

\section{B. Leaf sampling and processing}

The leaves of Habenaria foliosa were collected in the sterile ziplock bags from sites mentioned above.Care was taken to avoid contact of external environment during travelling. The leaf samples were brought to the laboratory as soon as possible so as to avoid the shrinkage of leaves after being detached from the mother plant.

\section{Isolation of Phylloplane fungi}

For to access the Phylloplane diversity, four different fungal growth media viz. Potato Dextrose Media (PDA), Czapex Dox Agar Media (CzA), Malt extract Peptone Dextrose Media (MEA), Rose Bengal Agar Media (RBA) were used. The leaf dilution method was employed for the isolation of fungal flora as suggested by the Aneja2004 [1]. 
Vol. 4, Issue 5, May 2017

\section{Identification of fungi}

The isolated fungi were identified using the standard literature like A Manual of Aspergilli[16], Illustrated Genera of Imperfect Fungi[2] and Handbook of Soil Fungi[10].

\section{E. Data analysis}

The data generated from observations was used to calculate Frequency, Shannon Diversity Index and Simpson Diversity Index.

\section{RESULTS AND DISCUSSION}

The output of the present investigation is that a total of 111 fungal colonies were isolated from the leaf surface of Habenaria foliosa which was collected from two different districts of Maharashtra. The total mycoflora comprises of the 22 fungal taxa representing 13 genera. The isolated fungal taxawere representingthree groups viz. Zygomycota, Anamorphic fungi and the Sterile Group.

Zygomycota contribute $4.5 \%$ to the total mycoflora. In this group only three species were isolated out of which Phycomycesnitens were found to be dominant over other two. Anamorphic fungi isolated at the frequency of $72.1 \%$. The diversity of this group is noted by 17 fungal species and 8 genera. The Penicillium was found to be predominant with $28.8 \%$ followed by the Aspergillus which was isolated at the frequency of $19.8 \%$. Six different species of Aspergillus were isolated. Aspergillus nigershows its dominance with 6.3\% (Table: I).

Four different fungal growth media were used for the present investigation. Bhandara district contribute near about $29 \%$ while those of Gadchiroli district contribute $71 \%$. From the Gadchiroli district 19 fungal colony counts was observed for PDA, 23 forCzA, 23 for MEA and 14 for RBA. The sterile mycelia groupwas present at the rate of $23 \%$ (Table: I).

\section{Diversity index}

The diversity index was calculated using PAST 3.12.The maximum Simpson Diversity index was reported from Gadchiroli district over CzA i.e. 0.8922 and the minimum in Bhandara district over CzA i.e. 0.625. The Shannon Diversity index also showed similarity with Simpson index with respect to the media, district, min and max (Table: II).

The study reveals that the overall Phylloplane microbial diversity was found to be associated with the Habenaria foliosa was represented by the 22 fungal species including 13 fungal genera. The diverse isolates obtained over the different fungal media proved that the Leaf Dilution method is good one for the present type of study which was also supported by,Wahab 1975 [17], Borgohain et al 2014 [4].

Every fungus needs some basic elements and carbon source for the growth and development which it obtains from the respective environment. The growth response of the every fungus is varying to the respective media. Fungi are nutritionally so diverse,no single medium could be used for isolation of all the fungi. Some fungi require specific elements for the growth and sporulation so the diversity of fungi must be recorded over diverse fungal media as like we recorded in present study like PDA, CzA, MEA, RBA. The use of these media for the microfungal study was also done by Banakar et al 2012 [3].

Habenaria foliosa harbour greater Phylloplane diversity. It is represented by the 111 fungal colonies over 4 different growth media from the 2 different districts of Maharashtra state of India. In our investigation we encountered only three members of Zygomycota,Actinomucor and Rhizopus were found to be present only in the Gadchiroli district whereas Phycomycesnitens was isolated from the both the districts and it is dominated over other two genera at the frequency of $2.7 \%$ (Table-I).

Out of total isolated fungi, maximum diversity was noted in the group of Anamorphic fungi. Altogether 17 species are encountered out of 22 from this group. Penicillium showed the maximum dominance at the frequency of $28.8 \%$ followed by the Aspergillus (19.8\%) over all other fungal species. The maximum dominance of these fungi in the Phylloplane is probably because of their high spore production and easy dispersion in the forest. Habenaria foliosa is small plant, grown in the rainy season at the strata of forest floor.

Plant height and the leaf sheath are the probable factors that increase the chances of spore settlement over leaf surface. The forest floor is highly nutritious for the microbial growth. The highest dominance of Aspergillus and Penicillium from the forest area was also reported by the Saravanakumar\&Kaviyarasan 2010 [13],Banakar et al 2012 [3], similar dominance of Aspergillus and Penicillium was also recorded in our investigation.

Aspergillus showed its dominance by six different species. Out of that only two, Aspergillus niger and Aspergillus sulphureus, were isolated from Bhandara district whereas all six species were dominantly present in the Gadchiroli 
district. Penicillium was isolated with three different species out of which P. oxalicum was found to the most dominant in both the site. Other fungal genera like Alternaria, Curvularia, Fusarium, Pestolopsis, Torula, Trichoderma were isolated at moderate frequency. Sterile mycelia both white and black were found to be dominant after Aspergillus and Penicillium (Table-I).

The statistical analysis of isolated fugal flora showed that the values of Simpson's diversity index and Shannon diversity index for both the district were significantly differ from each other. Diversity index clearly justify that the diversity of Phylloplane fungi is more in Gadchiroli district as compared to the Bhandara district. The forest of Gadchiroli harbours the tremendous diversity of Plants and Animals [14]. It is bestowed with the good soil profile, heavy rain fall and thick dense forest. All these factors lead to increase the humus over the forest floor which ultimately supports the maximal microbial population. This is the most probable reason to get the more fungal diversity from the Gadchiroli forest.

\section{CONCLUSIONS}

From the present investigation it was concluded that the Phylloplane of Habenaria foliosa harbour the tremendous diversity of fungi. A total of 22 fungal species belonging to 13 genera were isolated from the Phylloplane of respective plant. The leaf dilution method was also found to be the good one for the isolation of Phylloplane fungi. The view that different fungi need different requirement was also proved from then use of different media for isolation. Among the isolate, Aspergillus and Penicillium were recorded as the most dominant fungi followed by the black sterile mycelia. Other fungus like Alternaria, Curvularia, Fusarium, Pestolopsis, TrichodermaandTorula are at moderate frequency. The overall data and its statistical analysis revealed that the Phylloplane mycoflora was more diverse in plants from the forest of Gadchiroli as compared to that of Bhandara.

\section{ACKNOWLEDGEMENTS}

The authors are thankful to the Head of Department of Botany, Rashtrasant Tukadoji Maharaja Nagpur University Nagpur for the providing necessary facilities and the Ministry of Environment, Forests and Climate Change (MoEF\& $\mathrm{CC})$ for financial help.

\section{REFERENCES}

[1] Aneja KR. 2004. Experiments on Microbiology, Plant Pathology and Biotechnology.4th ed., New Delhi: New Age International Pvt.Ltd.

[2] Barnett HL, Hunter BB. 1972 - Illustrate Genera of Imperfect Fungi. Burgess publishing company.

[3] Banakar S. Thippeswamy B, Thirumalesh B, Naveenkumar K, 2012 -Diversity of soil fungi in dry deciduous forest of Bhadra Wildlife Sanctuary,Western Ghats of southern India.Journal of Forestry Research 23,631-640.

[4] Borgohain1 A, Das R and Chutia M. 2014 - Fungal Diversity in phylloplane of castor plant (RicinuscommunisL): the primary food plant of Eri Silkworm Scholarly Journal of Agricultural Science 4, 82-86.

[5] Fenn M, Paul H. Dunn P, Durall D 1989 - Effects of Ozone and Sulfur Dioxide on Phyllosphere Fungi from Three Tree Species Applied And Environmental Microbiology 55, 412-418

[6] Jalal JS, Jayanthi J. 2012 - Endemic orchids of peninsular India: a review. Journal of Threatened Taxa 4(15), 3415-3425.

[7] Joshi V,Janarthanam M. 2004 - The diversity of life-form type, habitat preference and phenology of the endemics in the Goa region of the Western Ghats, India. Journal of Biogeography 31, 227-1237.

[8] Langvad F. 1980 - A simple and rapid method for qualitative and quantitative study of the fungal flora of leaves. Canadian Journal of Microbiology 26, 666-670.

[9] Machaka-Houri N, Al-Zein MS, Westbury DB, Talhouk SN 2012 - Reproductive success of the rare endemic Orchisgalilaea (Orchidaceae) in Lebanon. Turkish Journal of Botany 36, 677-682.

[10] Nagamani A, Kunwar IK, Manocharachary C. 2006 -Handbook of Soil Fungi. I K International Pvt. Ltd.

[11] Norse D. 1972 -Fungal populations of tobacco leaves and their effect on the growth of Alternaria longipes. Transactions of the British Mycological Society 59, 261-271.

[12] Saha A, Ray A, Das P. 2013 - Fungal Colonization of Phylloplane of PsidiumGuineenseSw. Growing In Suryamaninagar, Tripura, Northeast India International Journal of Basic and Applied Chemical Sciences 3 (1), 62-67.

[13] Saravanakumar K, Kaviyarasan V. 2010 -Seasonal distribution of soil fungi and chemical properties of montane wet temperate forest types of Tamil Nadu. African Journal of Plant Science 4, 190-196.

[14] Setiya A, Narkhede S, Dongarwar N. 2016 - Exploration and Documentation of Some Scarcity Food Plants Used By the Aboriginals from Gadchiroli District (M.S.) India International Advanced Research Journal in Science, Engineering and Technology 3, 69-73.

[15] Singh NP, Karthikeyan S, Sharma BD. 1996 - Flora of Maharashtra state- Monocotyledons. BSI Calcutta.

[16] Thom C, Raper KB. 1945- A manual of Aspergilli. The Williams and Wilkins Company, Baltimore.

[17] Wahab A. 1975 - PhyllosphereMicroflora of Some Egyptian Plants. Folia Microbiol. 20, 236-245. 
Vol. 4, Issue 5, May 2017

\begin{tabular}{|c|c|c|c|c|c|c|c|c|c|c|c|c|c|c|}
\hline \multicolumn{15}{|c|}{ Table I: Phylloplane mycoflora of Habenaria foliosa from two different districts of Maharashtra. } \\
\hline \multirow[b]{2}{*}{$\begin{array}{l}\mathrm{Sr} \\
\text { no }\end{array}$} & \multirow[b]{2}{*}{$\begin{array}{l}\text { Fungal } \\
\text { organism }\end{array}$} & \multicolumn{4}{|c|}{ Bhandara } & \multirow{2}{*}{$\begin{array}{l}\text { Total } \\
\text { (S-I) }\end{array}$} & \multicolumn{4}{|c|}{ Gadchiroli } & \multirow{2}{*}{$\begin{array}{l}\text { Total } \\
\text { (S-II) }\end{array}$} & \multirow{2}{*}{$\begin{array}{c}\text { Total } \\
\text { colonies } \\
\text { (S-I + } \\
\text { S-II) }\end{array}$} & \multicolumn{2}{|c|}{ Frequency } \\
\hline & & $\begin{array}{c}\mathrm{PD} \\
\mathrm{A}\end{array}$ & CzA & MEA & $\begin{array}{c}\mathrm{RB} \\
\mathrm{A}\end{array}$ & & PDA & CzA & $\begin{array}{c}\text { ME } \\
\text { A }\end{array}$ & $\begin{array}{c}\mathrm{RB} \\
\mathrm{A}\end{array}$ & & & $\begin{array}{c}\text { specie } \\
\text { s }\end{array}$ & $\begin{array}{c}\text { gener } \\
\text { a }\end{array}$ \\
\hline & Zygomycota & 1 & - & - & 1 & $2(1.8)^{*}$ & - & 1 & 2 & - & $3(2.7)^{*}$ & & \multicolumn{2}{|c|}{4.5} \\
\hline 1. & $\begin{array}{l}\text { Actinomucorel } \\
\text { egans }\end{array}$ & - & - & - & - & - & - & - & 1 & - & $1(0.9)$ & 1 & 0.9 & 0.9 \\
\hline 2. & $\begin{array}{l}\text { Phycomycesnit } \\
\text { ens }\end{array}$ & 1 & - & - & 1 & $2(1.8)$ & - & - & 1 & - & $1(0.9)$ & 3 & 2.7 & 2.7 \\
\hline \multirow[t]{2}{*}{3.} & $\begin{array}{l}\text { Rhizopus } \\
\text { stolonifer }\end{array}$ & - & - & - & - & - & - & 1 & - & - & $1(0.9)$ & 1 & 0.9 & 0.9 \\
\hline & $\begin{array}{l}\text { Anamorphic } \\
\text { fungi }\end{array}$ & 4 & 1 & 4 & 4 & $13(11.7)$ & 17 & 19 & 18 & 13 & $67(60.4)$ & 80 & \multicolumn{2}{|c|}{72.1} \\
\hline 4. & $\begin{array}{l}\text { Alternaria } \\
\text { alternata }\end{array}$ & - & - & - & - & - & - & - & - & 1 & $1(0.9)$ & 1 & 0.9 & \multirow{2}{*}{3.6} \\
\hline 5. & $\begin{array}{l}\text { Alternaria } \\
\text { brassicicola }\end{array}$ & - & - & - & - & - & - & 1 & 2 & - & $3(2.7)$ & 3 & 2.7 & \\
\hline 6. & $\begin{array}{l}\text { Aspergillus } \\
\text { aculeatus }\end{array}$ & - & - & - & - & - & - & 2 & - & - & $2(1.8)$ & 2 & 1.8 & \multirow{6}{*}{19.8} \\
\hline 7. & $\begin{array}{l}\text { Aspergillus } \\
\text { caespitosus }\end{array}$ & - & - & - & - & - & - & 1 & - & - & $1(0.9)$ & 1 & 0.9 & \\
\hline 8. & $\begin{array}{l}\text { Aspergillus } \\
\text { japonicus }\end{array}$ & - & - & - & - & - & 1 & - & - & - & $1(0.9)$ & 1 & 0.9 & \\
\hline 9. & $\begin{array}{l}\text { Aspergillus } \\
\text { niger }\end{array}$ & 1 & - & 2 & - & $2(1.8)$ & 2 & - & 2 & - & $4(3.6)$ & 7 & 6.3 & \\
\hline 10 & $\begin{array}{l}\text { Aspergillus } \\
\text { ochraceous }\end{array}$ & - & - & - & - & - & - & - & - & 5 & $5(4.5)$ & 5 & 4.5 & \\
\hline 11 & $\begin{array}{l}\text { Aspergillus } \\
\text { sulphureus }\end{array}$ & - & - & - & 3 & $3(2.7)$ & - & 1 & - & 2 & $3(2.7)$ & 6 & 5.4 & \\
\hline 12 & $\begin{array}{l}\text { Curvularia } \\
\text { lunata }\end{array}$ & - & - & - & - & - & 1 & - & 2 & - & $3(2.7)$ & 3 & 2.7 & 2.7 \\
\hline 13 & $\begin{array}{l}\begin{array}{l}\text { Fusarium } \\
\text { moniliformae }\end{array} \\
\text { n }\end{array}$ & - & - & - & 1 & $1(0.9)$ & - & 1 & - & 2 & $3(2.7)$ & 4 & 3.6 & \multirow{2}{*}{4.5} \\
\hline 14 & $\begin{array}{l}\text { Fusarium } \\
\text { oxysporum }\end{array}$ & - & - & - & - & - & - & 1 & - & - & $1(0.9)$ & 1 & 0.9 & \\
\hline 15 & $\begin{array}{l}\text { Penicillium } \\
\text { oxalicum }\end{array}$ & 2 & 1 & - & - & $3(2.7)$ & 13 & 3 & 8 & 2 & $26(23.4)$ & 29 & 26.1 & \multirow{3}{*}{28.8} \\
\hline 16 & $\begin{array}{l}\text { Penicillium } \\
\text { roqueforti }\end{array}$ & - & - & - & - & - & - & 2 & - & - & $2(1.8)$ & 2 & 1.8 & \\
\hline 17 & $\begin{array}{l}\text { Penicilliun } \\
\text { spp. }\end{array}$ & - & - & - & - & - & - & - & 1 & - & $1(0.9)$ & 1 & 0.9 & \\
\hline 18 & $\begin{array}{l}\text { Pestoliopsisgla } \\
\text { ndicola }\end{array}$ & - & - & - & - & - & - & 5 & 3 & - & $8(7.2)$ & 8 & 7.2 & 7.2 \\
\hline 19 & $\begin{array}{l}\text { Torula } \\
\text { herbarum }\end{array}$ & - & - & - & - & - & - & 2 & - & - & $2(1.8)$ & 2 & 1.8 & 1.8 \\
\hline 20 & $\begin{array}{l}\text { Trichodermavi } \\
\text { ride }\end{array}$ & 1 & - & 2 & - & $3(2.7)$ & - & - & - & 1 & $1(0.9)$ & 4 & 3.6 & 3.6 \\
\hline & Other Types & 4 & 3 & 4 & 6 & 17(15.3) & 2 & 3 & 3 & 1 & $9(8.1)$ & 26 & \multicolumn{2}{|c|}{23.4} \\
\hline 21 & $\begin{array}{l}\text { White sterile } \\
\text { mycelia }\end{array}$ & 1 & 1 & 2 & 3 & $7(6.3)$ & 1 & 1 & 1 & - & $3(2.7)$ & 10 & 9 & 9 \\
\hline \multirow[t]{2}{*}{22} & $\begin{array}{l}\text { Black sterile } \\
\text { mycelia }\end{array}$ & 3 & 2 & 2 & 3 & $10(9)$ & 1 & 2 & 2 & 1 & $6(5.4)$ & 16 & 14.4 & 14.4 \\
\hline & TOTAL & $\begin{array}{c}9 \\
(8 . \\
1)\end{array}$ & $\begin{array}{c}\mathbf{4} \\
(3.6)\end{array}$ & $\begin{array}{c}\mathbf{8} \\
(7.2)\end{array}$ & $\begin{array}{c}11 \\
(9.9)\end{array}$ & $\begin{array}{c}\mathbf{3 2} \\
(28.8)\end{array}$ & $\begin{array}{c}\mathbf{1 9} \\
(17 . \\
1)\end{array}$ & $\begin{array}{c}\mathbf{2 3} \\
(20.7 \\
)\end{array}$ & $\begin{array}{c}\mathbf{2 3} \\
(20.7 \\
)\end{array}$ & $\begin{array}{c}\mathbf{1 4} \\
(12 . \\
6)\end{array}$ & $\begin{array}{c}79 \\
(71.1)\end{array}$ & 111 & 99.9 & 99.9 \\
\hline
\end{tabular}

\begin{tabular}{|c|c|c|c|c|c|c|c|c|}
\hline \multicolumn{10}{|c|}{ Table - II : Diversity Index } \\
\hline & Simpson (1-D) Diversity Index & \multicolumn{5}{c|}{ Shannon (H) Diversity Index } \\
\hline & PDA & CzA & MEA & RBA & PDA & CzA & MEA & RBA \\
\hline Bhandara & 0.7901 & 0.625 & 0.75 & 0.7603 & 1.677 & 1.04 & 1.386 & 1.499 \\
\hline Gadchiroli & 0.5097 & 0.8922 & 0.8242 & 0.7959 & 1.117 & 2.401 & 2.028 & 1.767 \\
\hline
\end{tabular}

